\title{
Realitas Perkawinan Beda Agama Perspektif Keluarga Sakinah
}

\section{Nova Effenty Muhammad}

IAIN Sultan Amai Gorontalo

Email: nova.alhakim@yahoo.com

\begin{abstract}
This paper concentrates on a happy family in an interfaith marriage. According to the majority ulama, marriage is a theological activity that a couple of interfaith marriage will not a happy family. In this paper to examine the interfaith marriage couple can be a happy family. Specifically, how to concept a happy family according to the interfaith married couples? Further, how to manage family conflict in interfaith marriage to get a happy family? To analyze a happy family on interfaith marriage couple. This is paper use a qualitative analysis method with three approaches: Islamic law, sociology, and psychology context with the use of data collection methods with observation, interviews, and documents. This research argues that religion is not a major factor in a happy family because interfaith marriage can be a happy family. Worries ulama that interfaith couples cannot be a happy family does not happen. The contribution of this study as the antithesis according to ulama about interfaith marriage, that happiness is not correlated with religion.
\end{abstract}

Keywords: Islamic Law, Interfaith Marriage, Happy Family

\section{The Reality of Interfaith Marriage Perspective Happy Family}

\begin{abstract}
Abstrak: Artikel ini berkonsentrasi pada keluarga bahagia dalam pernikahan beda agama. Menurut mayoritas ulama, perkawinan adalah kegiatan teologis bahwa perkawinan beda agama tidak akan menjadi keluarga yang bahagia. Dalam tulisan ini, saya mengkaji pasangan nikah beda agama bisa menjadi keluarga bahagia. Secara khusus, bagaimana konsep keluarga bahagia menurut pasangan suami-istri beda agama? Selanjutnya bagaimana menangani konflik keluarga dalam perkawinan beda agama untuk mendapatkan keluarga yang bahagia? Menganalisis keluarga bahagia pada pasangan nikah beda agama. Artikel ini menggunakan metode analisis kualitatif dengan tiga pendekatan, yaitu hukum Islam, konteks sosiologi, dan psikologi dengan menggunakan metode pengumpulan data berupa observasi, wawancara, dan dokumen. Hasil penelitian menunjukkan agama bukanlah faktor utama dalam keluarga bahagia karena pernikahan beda agama bisa menjadi keluarga bahagia. Kekhawatiran ulama bahwa pasangan beda agama tidak bisa menjadi keluarga bahagia tidak terjadi. Kontribusi penelitian ini sebagai antitesis menurut ulama tentang nikah beda agama, bahwa kebahagiaan tidak berhubungan dengan agama.
\end{abstract}

Kata Kunci: Hukum Islam, Pernikahan Beda Agama, Keluarga Bahagia 


\section{A. Pendahuluan}

Manusia dalam berinteraksi dengan sesamanya pastilah membutuhkan petunjuk dalam menjalani kehidupan sosialnya, baik itu petunjuk agama maupun aturan negara. Hal ini dikarenakan dalam interaksi tersebut tidak selamanya berjalan dengan baik, saling menguntungkan, akan tetapi bisa jadi menimbulkan sebuah masalah. Salah satu masalah yang menyangkut hubungan antar manusia yang dalam perspektif agama Islam diistilahkan muāmalat duniawiyat adalah masalah perkawinan (al-munākaḥat) dengan segala persoalan yang berada di sekitarnya mendapatkan perhatian yang istimewa. ${ }^{1}$ Keistimewaan ini dikarenakan perkawinan adalah sebuah penyatuan dua insan yang berbeda.

Hidup bersama merupakan suatu fenomena yang merupakan kodrat bagi setiap manusia dan mengingat manusia merupakan makhluk sosial. Dalam bentuknya yang terkecil, hidup bersama itu dimulai dengan adanya keluarga, di mana lembaga perkawinan merupakan dasar peradaban umat manusia dan tempat bagi manusia untuk mengabdikan diri dan saling menghormati perasaan pasangannya. ${ }^{2}$

Perkawinan merupakan ketetapan Allah swt. atas segala makhluknya. ${ }^{3}$ Namun perkawinan manusia berbeda dengan perkawinan makhluk-makhluk lainnya. Secara simbolik Alquran menyebutnya mitsaqan ghalizan. ${ }^{4}$ Penekanan yang tegas tentang makna ikatan perkawinan, bahwa ia adalah suatu ikatan yang kokoh, yang tidak boleh dirobek-robek dan dihancurkan. Pemahaman ayat ini sangat terkait dengan makna 'mitsaqan' yakni piagam perjanjian, persetujuan dan ikatan yang meresap ke dalam jiwa dan sanubari. ${ }^{5}$ Selain itu, perkawinan tidak lepas dari unsur-unsur mentaati perintah Allah dan melaksanakannya, termasuk aspek ' ubudiyyah (pengabdian/ibadah).

\footnotetext{
${ }^{1}$ Musthafa Kamal, et. al., Fikih Islam (Yogyakarta: Citra Karsa Mandiri, 2002), 243.

${ }^{2}$ Lili Rasjidi, Hukum Perkawinan dan Perceraian di Malaysia dan di Indonesia (Bandung: PT Remaja Rosdakarya, 1991), 1.

${ }^{3}$ Lihat QS Yāsin/36: 36 dan QS al-Zariyāt/51: 49

${ }^{4}$ Lihat QS al-Nisā'/4: 21.

${ }^{5}$ Mahmud Syalthut, Al-Islam 'Aqidah wa Syari'ah, terj. Bustami dan Hamdani, Akidah dan Syari'ah Islam (Jakarta: Bulan Bintang, 1972), 109.
} 
Ikatan perkawinan sebagai mitsaqan ghalizan dan mentaati perintah Allah bertujuan untuk membina dan membentuk hubungan ikatan lahir dan batin antara seorang laki-laki dan seorang perempuan sebagai suami istri dalam kehidupan rumah tangga yang bahagia dan kekal berdasarkan syariat Islam. ${ }^{6}$ Dalam Alquran tidak dijumpai satu ikatan perjanjian pun yang diberi penekanan dan predikat 'mitsaqan ghalizan, selain dari ikatan perkawinan. Allah memberi sebutan dan kualitas khusus pada ikatan perkawinan sebagai suatu piagam perjanjian yang kokoh, guna membedakannya dari bentuk perikatan atau perjanjian yang lain. ${ }^{7}$ Jika perjanjian yang lain seperti jual beli atau perjanjian antar bangsa oleh Alquran dikelompokkan dengan perjanjian biasa dengan sifat yang menonjolkan hubungan perdata dan materil, maka lain halnya dengan ikatan perkawinan.

Ikatan perkawinan tidak hanya terbatas pada hubungan fisik dan materil, akan tetapi sekaligus lebih menitikberatkan pada ikatan batin atau ikatan jiwa yang mendalam yang terhunjam ke dalam sanubari. Allah swt. menciptakan bagi manusia pasangan jodoh (suami istri) dalam sebuah ikatan perkawinan dalam sebuah mahligai rumah tangga guna mewujudkan keluarga sakinah, mawaddah wa rahmah (rasa kasih dan sayang) ${ }^{8}$ yang merupakan kebutuhan batin antara suami istri tersebut. Selain itu perkawinan hendaklah membawa kesenangan dalam kebersamaan, bahkan lebih jauh mengibaratkan lekatnya hubungan ikatan jiwa antara suami istri harus sampai pada pencapaian keharmonisan dalam keluarga. ${ }^{9}$

Permasalahannya kemudian jika tujuan perkawinan adalah untuk menciptakan keluarga sakinah mawaddah wa rahmah bisa diperoleh bagi perkawinan beda agama ataukah tidak, karena persoalan perkawinan beda agama pada sebagian orang masih

\footnotetext{
${ }^{6}$ H. S. A. Alhamdani, Risalatun Nikah, terj. Agus Salim, Risalah Nikah: Hukum Perkawinan Islam (Jakarta: Pustaka Amani, 1980), 68.

${ }^{7}$ Sayuti Talib, Hukum Kekeluargaan Indonesia (Cet. II; Jakarta: UI Press. 1982), 41.

${ }^{8}$ Lihat QS al-Rūm/30: 21.

${ }^{9}$ Rizal Darwis, "Hak Nafkah Batin Istri dalam Perkawinan: Telaah Fikih dan Hukum Nasional Perspektif Jender,” Disertasi (Makassar: UIN Alauddin Makassar, 2016), 1-2.
} 
menjadi polemik terhadap keabsahannya. Hal ini juga menjadi perhatian ulama-ulama di Indonesia, khususnya pada Majelis Ulama Indonesia (MUI).

Pada 1 Juni 1980, MUI mengeluarkan fatwa tentang kawin beda agama. Fatwa mengeluarkan dua ketetapan, yaitu: Pertama, bahwa seorang perempuan yang beragama Islam tidak boleh dikawinkan dengan seorang laki-laki yang bukan beragama Islam. Kedua, bahwa laki-laki beragama Islam tidak diizinkan menikahi seorang perempuan yang bukan beragama Islam, termasuk Kristen (ahl al-kitab). Fatwa ini ditandatangani oleh Hamka sebagai Ketua Umum dan Kafrawi sebagai Sekretaris MUI. ${ }^{10}$

Perkawinan beda agama adalah penyatuan lahir dan batin antara satu orang pria dengan satu orang wanita menjadi suami istri dengan tujuan membangun keluarga (rumah tangga) yang bahagia dan kekal, sedang keduanya berbeda agama. ${ }^{11}$ Perkawinan beda agama adalah termasuk isu kontemporer dan kontroversial di Indonesia. Dikatakan kontroversial, karena wacana pernikahan beda agama diramaikan oleh pendapat yang pro dan kontra. Kelompok yang mengharamkan pernikahan beda agama merujuk kepada Q.S. al-Baqarah: 221. Ayat ini dengan tegas melarang menikahi wanita musyrikah. Jika merujuk kepada interpretasi ulama terhadap term musyrik sebagaimana disebutkan, maka orang musyrik adalah mereka yang tidak menganut agama tertentu. Oleh karena itu, term musyrik dibedakan dengan term ahl al-kitab. Ahl al-kitab ini merujuk kepada agama tertentu, yang ditafsirkan oleh mayoritas ulama sebagai Yahudi dan Nasrani.

Selain merujuk kepada QS al-Baqarah/2: 221, kelompok yang tidak membolehkan perkawinan beda agama juga menjadikan QS al-Mâidah/5: 5 sebagai dasar hukumnya. Secara literal QS al-Mâidah/5: 5 ini berbeda dengan QS al-Baqarah/2: 221. Pada QS al-Baqarah/2: 221 dengan tegas berisi larangan menikahi wanita

\footnotetext{
${ }^{10}$ Nova Effenty Muhammad, "Perkawinan Beda Agama Menurut Tinjauan Hukum Islam: Studi Atas Fatwa MUI Tahun 2005," Disertasi (Makassar: UIN Alauddin Makassar, 2016), 32.

${ }^{11}$ Sofyan A. P. Kau, Tafsir Hukum Tema-Tema Kontroversial (Yogyakarta: Mitra Pelajar, 2013), 1 .
} 
musyrik. Sedangkan QS al-Mâidah/5: 5 justru berisi kebolehan menikahi wanita ahl alkitab. Oleh karena itu, ayat ini menjadi dasar argumentatif kelompok yang membolehkan pernikahan beda agama. Meskipun secara literal ayat ini menunjukkan kebolehan nikah beda agama, namun dipahami sebaliknya oleh kelompok yang mengharamkan. Dengan ungkapan lain, kelompok yang mengharamkan menjadikan ayat ini sebagai dalil atas larangan menikahi wanita ahl al-kitab. Argumen yang dibangun atas keharamannya adalah dilatarbelakangi oleh keinginan menciptakan "sakinah" dalam keluarga yang merupakan tujuan perkawinan. Perkawinan baru akan langgeng dan tenteram jika terdapat kesesuaian pandangan hidup antara suami-istri. Jangankan perbedaan agama, perbedaan budaya bahkan tingkat pendidikan pun tidak jarang menimbulkan kesalahpahaman dan kegagalan perkawinan. ${ }^{12}$

Bila dicermati pelarangan nikah beda agama tidak didasarkan atas nash, karena nash QS al-Mâidah/5: 5 tidak menegaskan pelarangannya, justru pembolehan atasnya. Penyimpulan hukum tersebut lebih didasarkan pada pertimbangkan dampak negatif yang lebih besar jika nikah beda agama itu diperkenankan. Namun berbeda Surat Keputusan Nomor: 4/MUNAS VII/MUI/8/2005 tentang Perkawinan Beda Agama, diputuskan bahwa perkawinan beda agama adalah haram dan tidak sah. Untuk memperkuat fatwa tersebut, Majelis Ulama Indonesia (MUI) menggunakan kaedah fikih: "mencegah kemafsadatan lebih didahulukan (diutamakan) dari pada menarik kemaslahatan" dan kaedah "sadd al-zarî’ah." Berdasarkan kaedah ini, MUI memandang bahwa perkawinan beda agama berdampak negatif, tidak akan mencapai tujuan pernikahan keluarga yang sakinah, mawaddah, warahmah dan karena itu harus dicegah. Upaya pencegahan tersebut dinamakan sadd al-zarî’ah. Kaedah ini menegaskan bahwa jalan atau sarana yang mengarah kepada kerusakan harus dicegah demi mencapai kemaslahatan.

\footnotetext{
${ }^{12}$ M. Quraish Shihab, Tafsir al-Mishbah Pesan, Kesan dan Keserasian Al-Quran, Vol. 3 (Jakarta: Lentera Hati, 1421 H/2001 M), 28-30.
} 
MUI berpandangan bahwa pernikahan adalah kegiatan teologi sehingga untuk mencapai tujuan keluarga yang sakinah maka selayaknya perkawinan harus seagama. Artinya pasangan yang melakukan perkawinan beda agama tidak dapat mencapai tujuan perkawinan menurut Islam, yaitu keluarga yang sakinah/bahagia. Namun jika melihat realitas perkawinan beda agama semakin bertambah di Indonesia. Data yang terhimpun pasangan yang merenda kasih merajut asmara dalam beda agama trennya selalu naik.

Di Indonesia melalui Indonesia Conference on Religion and Peace (ICRP) memberikan wadah dalam menanggapi adanya tren perkawinan beda agama ini. Melalui Program Konseling dan Advokasi Keluarga Harmoni yang dikoordinatori oleh Ahmad Nurcholis memberikan layanan konseling, advokasi dan fasilitas nikah beda agama ini. Sejak November 2005 hingga Desember 2007 telah mencatat seratusan pasang muda-mudi yang hendak nikah beda agama. Dari seratusan itu, tercatat sekitar 60-an pasang yang berhasil dinikahkan, ${ }^{13}$ pada April 2017 sebanyak 772 pasangan beda agama yang telah dinikahkan, dan diakhir tahun September 2020 mencapai 1.146 pasangan perkawinan beda agama.

\section{B. Kebahagiaan: Pengertian, Unsur dan Aspek-Aspeknya}

Kebahagiaan merupakan salah satu bentuk kebutuhan rohani setiap manusia. Kebahagiaan menduduki posisi yang utama dalam mencapai tujuan kehidupan manusia. Setiap manusia mengharapkan hari-harinya dipenuhi oleh kebahagiaan. Kebahagiaan terkadang dipandang oleh sebagian orang hanya berupa kecukupan materi duniawi, ada juga beranggapan jika bisa hidup tenang, dan lain sebagainya. Berdasarkan hal itu, maka para ilmuwan memberikan definisi terhadap apa yang dimaksud dengan kebahagiaan tersebut.

\footnotetext{
${ }^{13}$ Mohammad Monib dan Ahmad Nurcholish, Fiqh Keluarga Lintas Agama Panduan Multidimensi Mereguk Kebahagian Sejati, (Yogyakarta: Kaukaba Dipantara, 2013), xii.
} 
Kebahagiaan berasal dari bahasa Sansekerta, yaitu bhaga yang berarti jatah yang menyenangkan. ${ }^{14}$ Menurut Dahlan dan Muhtarom bahwa secara etimologi kebahagiaan itu berarti keadaan senang, tenteram, terlepas dari segala yang menyusahkan, sehingga kebahagiaan adalah sesuatu keadaan yang berlangsung, bukanlah suatu perasaan atau emosi yang berlaku. ${ }^{15}$ Dalam Kamus Besar Bahasa Indonesia (KBBI), kebahagiaan (kata benda) merupakan turunan dari bahagia (kata sifat) yang berarti kesenangan dan ketenteraman hidup (lahir batin); keberuntungan; kemujuran yang bersifat lahir batin. ${ }^{16}$ Menurut Kamus Umum, kebahagiaan adalah keadaan sejahtera dan kepuasan hati, yaitu kepuasaan yang menyenangkan yang timbul bila kebutuhan dan harapan tertentu individu terpenuhi. ${ }^{17}$ Khavari menyebutkan bahwa kebahagiaan berkaitan dengan keseimbangan material, intelektual, emosional dan spiritual. Saat berhadapan dengan masalah seperti apapun, seseorang yang mampu menyeimbangkan aspek-aspek tersebut akan dapat mengatasi masalah yang ada. ${ }^{18}$

Epicurus seorang filosof Yunani mengemukakan arti kebahagiaan sebagaimana dikutip Fakhruroji, yaitu happiness as serenity resulting from conquering basic fears (kebahagiaan adalah ketentraman atau ketenangan karena seseorang dapat menguasai kekhawatiran-kekhawatiran). ${ }^{19}$

Seligman misalnya menjelaskan kebahagiaan merupakan konsep yang mengacu pada emosi positif yang dirasakan individu serta aktivitas-aktivitas positif yang disukai oleh individu. Seligman juga mengklasifikasikan emosi positif menjadi tiga kategori yaitu berhubungan dengan masa lalu, sekarang dan masa depan. Emosi positif

\footnotetext{
${ }^{14}$ M. Dahlan R. dan Muhtarom, Menjadi Guru yang Bening Hati: Strategi Mengelola Hati di Abad Modern (Yogyakarta: Deepublish, 2016), 188.

${ }^{15}$ Ibid.

${ }^{16}$ Kementerian Pendidikan dan Kebudayaan RI, Kamus Besar Bahasa Indonesia Daring (Jakarta: Badan Pengembangan dan Pembinaan Bahasa, 2016), dalam https://kbbi.kemdikbud.go.id/entri/ kebahagiaan

${ }^{17}$ Elizabeth Bergner Hurlock, Psikologi Perkembangan: Suatu Pendekatan Sepanjang Rentang Kehidupan, Edisi V (Jakarta: Erlangga, 1991), 23

${ }^{18}$ Khalil A. Khavari, The art Of Happiness: Menciptakan Kebahagiaan dalam Setiap Keadaan (Jakarta. PT. Serambi Ilmu Semesta, 2006), 56.

${ }^{19}$ Moch. Fakhruroji, Instal Ulang Hidupmu: Menyulut Nyali untuk Melawan Virus Kehidupan (Bandung: Dar Mizan, 2006), 80.
} 
terkait dengan masa depan mencakup optimis, harapan, keyakinan, dan kepercayaan. Emosi positif terkait masa lalu mencakup kepuasan, pemenuhan, kebanggaan dan ketenangan sedangkan emosi positif berkaitan dengan masa kini adalah kesenangan. Pada kontras yang lebih tinggi kesenangan berasal dari kegiatan yang lebih kompleks dan mencakup perasaan seperti kebahagiaan. Lebih lanjut, Seligman menyebutkan kehidupan yang menyenangkan dan bermakna dapat menghasilkan kebahagiaan yang berasal dari pemanfaatan kekuatan- kekuatan psikologis. ${ }^{20}$

Menurut Aristoteles kebahagiaan harus diraih seumur hidup karena kebahagiaan adalah kehidupan yang baik, karena kebahagiaan adalah tujuan akhir dari keseluruhan hidup seorang manusia. ${ }^{21}$ Apakah seorang bahagia atau tidak dalam hidupnya hanya bisa dinilai setelah meninggal dunia. Mencermati pendapat Aristoteles maka kebahagiaan hanya didapat kepada ketika mati, sementara yang hidup dikatakan beruntung. Sementara bagaimana dengan orang yang hidup, apa yang dilakukan untuk mencapai kebahagiaan, setiap orang tentunya memiliki kriteria kebahagian yang berbeda-beda.

Hal yang berbeda untuk dapat memiliki kebahagiaan, yaitu dengan mengembangkan suatu hubungan atau interaksi yang hangat dan mendalam dengan orang lain. Muara dari hubungan itu adalah pada apa yang disebut dengan joy atau rasa suka cita. Rasa suka cita ini adalah suatu rasa bahagia yang intens dan mendalam yang sering didapatkan dari orang lain sebagai suatu bentuk penghargaan karena telah menjadi objek dari cinta, kasih sayang dan kekaguman Rasa suka cita ini seringkali diperoleh melalui interaksi antar individu yang dekat dan intim. Kemudian secara lebih lanjut, saat seseorang merasa bahagia, banyak dari mereka yang merefleksikan suka cita yang mereka rasakan kepada orang lain. ${ }^{22}$

\footnotetext{
${ }^{20}$ Martin Seligman, Aunthentic Happiness, Using the New Positive Psychology to Realize Your Potential for Lasting Fulfilment (New York: Free Press, 2002), 78-132.

${ }^{21}$ Moch. Fakhruroji, Instal Ulang Hidupmu, 80.

${ }^{22}$ Hendrick C., dan Hendrick S. S., Close Relationship: A Sourcebook (California: SAGE Publication, Inc. 2000), 101
} 
Sebuah penelitian sosial menunjukkan, salah satu pilar kebahagiaan hidup adalah jika seseorang memiliki teman atau komunitas yang baik, yang dimulai dari keluarga. Namun, hidup yang dibatasi hanya dalam jaringan keluarga juga tidak cukup sehingga seseorang senantiasa memerlukan relasi social dalam masyarakat. Di dalam masyarakat inilah sesungguhnya kita bisa mengaktualisasikan nilai-nilai agung yang menjadi sumber kebahagiaan hidup, seperti menolong atau berbagi kepada sesama teman, terutama mereka yang sedang dalam kesusahan. Jadi, sesungguhnya konsep dan pengalaman bahagia itu bermacam-macam, dan bisa juga dibuat hirarkinya. Konsep yang paling dekat adalah kebahagiaan yang dihajatkan oleh kebutuhan jasadi, lalu berkembang naik dengan terpenuhinya kebutuhan insani, yaitu intellectual happiness, moral happiness, social happiness, dan ada lagi aesthetical happiness, yakni rasa senang dan bahagia yang berkaitan dengan apresiasi dan aktivasi seni. ${ }^{23}$

Setiap orang cara meraih kebahagian dengan berbeda-beda tergantung pada diri masing-masing, tetapi namanya manusia mempunyai keterbatasan dalam hidup. Sesungguhnya konsep dan pengalaman bahagia itu bermacam-macam. Sebagian filosof menetapkan kebahagiaan sebagai landasan moral. Baik buruknya suatu tindakan diukur sejauh mana tindakan itu membawa orang pada kebahagiaan. Jika makan membuat orang bahagia, makan itu menjadi perbuatan baik. Jika makan banyak membuat orang sakit perut dan menderita, makan banyak menjadi perbuatan buruk. Tetapi yang lainnya mengatakan bahwa perbuatan baik dan buruk tidak ada hubungannya dengan kebahagiaan, karena ada tindakan yang membuat orang bahagia, tetapi disepakati tidak bermoral, mungkin koruptor berbahagia tetapi disepakati tidak bermoral.

Orang bahagia karena memiliki dan melakukan semua yang diinginkannya. Namun semua yang diinginkan, mesti tidak selalu ada. Sebagian orang merasa tidak semua yang diinginkan membuatnya bahagia. Bisa bahagia dengan meninggalkan keinginan yang tidak perlu, yang pemuasannya terlalu singkat. Tetapi ada keinginan

\footnotetext{
${ }^{23}$ Ibid., 102.
} 
orang yang lebih penting sehingga orang tersebut tidak bahagia, kalau tidak memiliki dan melakukannya. Kalau begitu kebahagiaan adalah mempunyai dan melakukan semua hal penting yang diinginkan. Menemukan orang yang berusaha bahagia hanya dengan mengejar satu saja yang diinginkan. Untuk itu, mengabaikan keinginankeingina lainnya. Ada orang yang mengejar kekayaan saja, dan meninggalkan hal-hal lain yang diinginkan seperti hubungan keluarga yang harmonis, keindahan, ketenangan batin. $^{24}$

Semua yang dirumuskan peneliti kebahagiaan adalah abstrak. Bahagia adalah emosi positif sementara sedih adalah emosi negatif. Emosi bisa diukur dengan mengukur gelombang otak kita secara objektif, ketika kita bahagia. Ini bisa diukur jika kita meneliti apakah misalnya orang bahagia cenderung menolong orang lain. Orang bahagia lebih sehat daripada orang sedih. Orang bahagia dapat membahagiakan orang lain. Kebahagiaaan ini disebut objektif, karena mengukurnya secara eksternal, di luar orang yang diteliti, seperti mengukur temperatur udara panas dan dingin dalam suhu ruangan. Dengan kata lain kebahagiaan itu subjektif, sehingga para peneliti menyebutnya subjectif well being (SWB).

Namun kebahagian tidak hanya terdiri dari perasaan, kebahagiaan juga meliputi penilaian seseorang tentang hidupnya. Perasaan ini disebut sebagai unsur afektif dan penilaian unsur kognitif. SWB diukur dengan emosi positif dan kepuasan pada kehidupan seseorang. Emosi positif boleh jadi berubah-ubah setiap saat. Merasakan bahagia kalau banyak merasakan emosi positif pada umumnya, dan menderita kalau pada banyak waktu melaporkan emosi negatif. ${ }^{25}$ Dengan kata lain bahwa kebahagiaan itu berangkat dari persepsi setiap orang atau individu dalam menjalani kehidupan di dunia ini.

${ }^{24}$ Jalaluddin Rakhmat, Meraih Kebahagiaan (Bandung: Simbiosa Rekatama Media, 2004), 102.

${ }^{25}$ Ibid., 107 
Selanjutnya kebahagiaan itu memiliki beberapa komponen atau aspek-aspek yang melingkupinya. Sebagaimana Diener menyebutkan bahwa kebahagiaan memiliki komponen, yaitu: apek positif, afek negatif dan kepuasan hidup. ${ }^{26}$

\section{Afek Positif dan Afek Negatif}

Afek positif merupakan perasaan-perasaan positif dalam diri individu yaitu: afek tertarik, bergairah, kuat, antusias, bangga, waspada, terinspirasi, penuh tekad, penuh perhatian dan aktif. Sedangkan afek negatif, merupakan perasaan-perasaan negatif dalam diri individu yaitu: afek tertekan, kecewa, bersalah, takut, memusuhi, gampang marah, malu, gelisah, gugup dan khawatir.

Afek positif dan afek negatif menggambarkan pengalaman utama dari situasi atau kejadian yang terus terjadi dalam kehidupan manusia. Penilaian afek terhadap situasi tertentu ikut mempengaruhi penilaian individu akan kesejahteraan subjektifnya. Dengan mengetahui tipe kecendrungan reaksi yang dialami individu, maka dapat diperoleh pemahaman tentang cara individu menilai kondisi dan kejadian yang terjadi dalam hidupnya.

Evaluasi afek terdiri dari emosi dan mood, dimana emosi bersifat lebih sementara karena merupakan respon situasi, sedangkan mood memiliki rentang yang lebih lama dari pada emosi. Orang yang bahagia adalah orang yang jarang mengalami afek negatif dan sering mengalami afek positif.

\section{Kepuasan Hidup}

Kepuasan hidup merupakan penilaian individu terhadap kualitas kehidupannya secara global. Penilaian umum atas kepuasan hidup merepresentasikan evaluasi yang berdasar kognitif dari sebuah kehidupan seseorang secara keseluruhan. ${ }^{27}$

\footnotetext{
${ }^{26}$ Diener E., Oishi S., dan Lucas R. E., "Personality, Culture, and Subjective Well-being: Emotional and Cognitive Evaluations of Life. Annual Review of Psychology, Vol. 54 (2003); 403-425. doi: 10.1146/annurev.psych.54.101601.

${ }^{27}$ Pavot W. dan Diener E., "The Affective and Cognitive Context of Selfreported Measures of Subjective Well-being. Social Indicators Research, Vol. 28 (1993); 1-20.
} 


\section{Perkawinan Beda Agama Perspektif Hukum Islam}

Posisi non muslim dalam wacana hukum Islam terdiri atas golongan ahl al-kitab dan musyrik. Ahl al-kitab adalah komunitas atau kelompok pemeluk agama yang memiliki kitab suci yang diwahyukan Allah kepada Nabi dan Rasul-Nya. ${ }^{28}$ Dengan merujuk kepada QS al-'Ankabut/29: 46 sebagian ahli tafsir berpendapat bahwa yang dimaksud dengan ahl al-kitab adalah Yahudi dan Nasrani. ${ }^{29}$ Sebagian mufassir tidak membatasinya dengan kelompok Yahudi dan Nasrani, melainkan juga memasukkan penganut agama Budha dan Hindu, bahkan Majusi, agama Persia kuno dan agama orang-orang India, Cina dan Jepang, juga termasuk ahl al-kitab. ${ }^{30}$ Sedangkan musyrik adalah golongan penyembah berhala (al-watsaniyyah), ateis (zindiqiyyah), murtad, penyembah api dan penganut aliran libertin (al-ibahah) seperti paham wujudiyyah. ${ }^{31}$ Selain ahl al-kitab dan musyrik, Alquran juga menyebut pemeluk agama Shabi'ah, ${ }^{32}$ Majusi $^{33}$ dan orang-orang yang berpegang pada shuhuf (lembaran kitab suci) Nabi Ibrahim yang bernama Syit dan shuhuf Nabi Musa yang bernama Taurat, ${ }^{34}$ serta kitab Zabur yang diturunkan kepada Nabi Dawud.

Dengan demikian, perkawinan beda agama bisa terjadi antara laki-laki muslim dengan perempuan ahl al-kitab (Yahudi, Kristen, Budha, Hindu, Kong Hu Chu); antara laki-laki muslim dengan perempuan musyrik; dan antara laki-laki muslim dengan perempuan Shabi'iyah, Majusi. Atau bisa juga sebaliknya, yaitu perkawinan antara perempuan muslimah dengan laki-laki ahl al-Kitab, musyrik, Shabi'iy dan Majusi.

Ajaran Islam melalui Alquran memandang salah satu tujuan perkawinan adalah menciptakan keluarga sakinah. Kata sakinah disebutkan dalam QS al-Rum/30: 21 yang artinya adalah ketentraman atau kenyamanan. Namun persoalan perkawinan beda

\footnotetext{
${ }^{28}$ Muhammad Galib M, Ahl al-Kitab Makna dan Cakupannya, (Yakarta: Paramadina, 1998), 20.

${ }^{29}$ Muhammad Husain al-Thabathab'i, Al-Mizan fi Tafsir al-Quran, Juz XVI (Beirut: Mu'assasah al-'Alami li al-Mathbu'at, 1983), 137.

${ }^{30}$ Rasyid Ridha, Tafsir al-Manar, Juz VI (Beirut: Dar al-Ma'arif, t. th.), 185 dan 193.

${ }^{31}$ Sayyid Sabiq, Fiqh as-Sunnah, Juz II (Beirut: Dar al-Fikr, 1985), 99.

${ }^{32}$ Lihat QS al-Baqarah/2: 62; QS al-Maidah/5: 69; QS al-Hajj/22: 17.

${ }^{33}$ Lihat QS al-Hajj/22: 17.

${ }^{34}$ Lihat QS al-A'la/87: 19.
} 
agama masih menjadi polemik oleh para ulama. Pendapat ulama mengatakan perkawinan beda agama haram tidak dapat mencapai keluarga yang sakinah, disandarkan pada kekhawatiran MUI dengan menggunakan kaedah fikih: "Mencegah kemafsadatan lebih didahulukan (diutamakan) dari pada menarik kemaslahatan" dan kaedah sadd al-zarî'ah.

Berdasarkan kaedah tersebut MUI memandang bahwa perkawinan beda agama berdampak negatif, tidak dapat mencapai keluarga sakinah sesuai dengan tujuan perkawinan dalam Islam, karena itu harus dicegah. Upaya pencegahan tersebut dinamakan sadd al-zarî'ah. Kaedah ini menegaskan bahwa jalan atau sarana yang mengarah kepada kerusakan harus dicegah demi mencapai kemaslahatan. -sebagaimana tujuan tulisan ini - untuk mengetahui apakah pendapat ulama bahwa pernikahan beda agama tidak dapat mencapai tujuan perkawinan yaitu membentuk keluarga yang sakinah dapat digunakan dua teori, yaitu teori hukum Islam, teori kebahagiaan.

Teori hukum Islam adalah merujuk pada empat produk pemikiran hukum Islam, yaitu fiqih, perundang-undangan di negeri-negeri muslim, keputusan pengadilan agama, dan fatwa-fatwa ulama. ${ }^{35}$ Sedangkan teori kebahagian adalah teori yang menunjukka rasa abstrak yang tentunya sulit diukur tapi dapat dirasakan, sehingga itu kebahagiaan tentunya memiliki unsur-unsur dan disebutlah bahwa itulah bahagia.

Berdasarkan QS al-Baqarah/2: 221, ulama tafsir sepakat keharaman mengawini wanita musyrik. Hanya saja mereka berbeda dalam menentukan siapa yang dimaksud dengan wanita orang musyrik tersebut. Menurut al-Qâsimî yang dimaksud dengan almusyrikât adalah perempuan penyembah berhala (al-waśaniyyât). ${ }^{36}$ Selain penyembah berhala, mereka juga tidak mempunyai kitab suci, tegas Ibnu Jarîr al-Tabarî (w. 310 H). Pendapat yang sama juga dikemukakan Yûsuf al-Qarḍawî. ${ }^{37}$ Menurut al-Râzî

\footnotetext{
${ }^{35}$ Sofyan A. P. Kau, Metode Penelitian Hukum Islam: Penuntun Praktis untuk Penulisan Skripsi dan Tesis (Yogyakarta: Mitra Pustaka, 2013), 11.

${ }^{36}$ Al-Qâsimî, Tafsîr Mahâsin al-Ta'wîl, Jilid III (Beirût: Dâr al-Fikr, 1978), 218.

${ }^{37}$ Y ûsuf al-Qarḍawî, Fî Fiqh al-Aqalliyyât al-Muslimah Hayâh al-Muslimîn wast al-Mujtama'ât al Ukhrâ, terj. Adillah Obid, Fiqh Minoritas Fatwa Kontemporer Terhadap Kehidupan Kaum Muslimin di Tengah Masyarakat Non Muslim (Jakarta: Zikrul Hakim, 2004 M), 117.
} 
mereka adalah orang yang mengingkari wujud Tuhan (ateis), tidak percaya kepada para nabi dan hari akhir dinamakan musyrik/musyrikah. ${ }^{38}$

Menurut Wahbah al-Zuhailî pelarangan pernikahan tersebut disebabkan tidak adanya keharmonisan, ketenangan dan kerjasama di antara suami istri. Karena perbedaan akidah menumbuhkan rasa gelisah dan ketidaktenangan, dan perpecahan di antara suami istri, sehingga kehidupan rumah tangga yang seharusnya berdiri di atas landasan sayang, kasih dan cinta tidak menjadi tenteram, dan tidak dapat tercapai tujuannya berupa ketenangan dan kestabilan. Kecuali itu, ketiadaan rasa keimanan terhadap suatu agama membuat seorang perempuan mudah untuk melakukan pengkhianatan rumah tangga, kerusakan dan keburukan; membuat hilang rasa amanah, kelurusan, dan kebaikan dari dalam dirinya, karena dia mempercayai takhayul dan imjinasi, serta terpengaruh dengan hawa nafsu dan tabiat diri yang tidak etis. Karena tidak ada agama yang mengekangnya, dan tidak ada yang mendorongnya untuk beriman kepada Allah, hari kiamat, hisab dan hari kebangkitan. ${ }^{39}$

Ayat lainnya dalam QS al-Mumtahanah/60: 10: menjelaskan jika dalam perkawinan ini dikhawatirkan perempuan yang beriman jatuh dalam kekafiran. Oleh karena biasanya suami mengajak istrinya untuk memeluk agamanya. Biasanya perempuan mengikuti suami mereka karena terpengaruh dengan perbuatan suaminya, dan mengikuti mereka dalam agama mereka. Terlebih diakhir ayat QS al-Baqarah/2: 221 juga disebutkan: “mereka mengajak ke neraka”. Maksudnya mereka mengajak para perempuan mukmin kepada kekafiran. Ajakan kepada kekafiran adalah ajakan kepada api neraka, karena kekafiran mendatangkan api neraka. Perkawinan perempuan mukmin dengan orang kafir merupakan sebab bagi ke arah yang haram. Ini adalah perkara yang haram. Meskipun bunyi teks ayat tersebut memaparkan tentang orangorang musyrik, tetapi yang menjadi 'illat (sebab) adalah ajakan ke api neraka,

\footnotetext{
${ }^{38}$ Fakhr al-Dîn al-Râzî, Tafsîr al-Kabîr wa Mafâtị̂h al-Ghayb, Jilid XVI (Bairut: Dar al-Fikr, 1981), 50 .

${ }^{39}$ Wahbah al-Zuhailî, Al-Fiqh al-Islâmî wa Adillatuhu, terj. Abdul Hayyie al-Kattani dkk., Fiqh Islam wa Adillatuhu, Jilid IX (Jakarta: Gema Insani Press, 2011), 148.
} 
mencakup semua orang kafir, maka hukum menjadi umum dengan keumuman 'illat. Tegasnya, berdasarkan ayat tersebut seorang muslimah tidak boleh menikah dengan orang laki-laki ahl al-kitab, sebagaimana dia juga tidak boleh menikah dengan orang majusi. Karena agama memutus penguasaan orang kafir terhadap orang mukmin berdasarkan QS al-Nisâ'/4: 141: “Allah sekali-kali tidak akan memberi jalan kepada orang-orang kafir untuk memusnahkan orang-orang beriman”. Jika orang kafir boleh menikah dengan perempuan mukmin, maka ada jalan baginya untuk mengajak kepada agamanya, dan ini tidak boleh. ${ }^{40}$

Mazhab Imamiyah juga sependapat dengan mazhab lain dalam hal tidak bolehnya muslimah menikah dengan orang kafir. Namun mereka berbeda pendapat dengan mazhab lain yang membolehkan muslim menikah dengan wanita ahlul Kitab. Sebagian ahli fikih, seperti Syaikh Mufîd, Sayyid al-Murtậâ dan Ibnu Barrâj berpendapat bahwa muslim tidak boleh menikah dengan mereka, baik dâim maupun munqati'. Pendapat mereka didasarkan atas QS al-Mumtahanah/60: 10: “Jangan kalian berpegangan dengan tali [pernikahan] orang-orang kafir" dan QS al-Nisâ'/4: 23: "Jangan kalian menikah dengan wanita-wanita musyrik sampai mereka beriman". Sedangkan sebagian lain, seperti 'Alî ibn Babâwaih dan Syaikh Ṣadûq mengatakan bahwa seorang muslim boleh menikah dengan wanita ahlul Kitab baik dâim maupun munqati'. Pendapat ini didasarkan atas surat al-Mâidah/5: 5: "[Dibolehkan menikah dengan] wanita-wanita mukmin dan wanita dari orang-orang yang memiliki Kitab sebelum kalian". Namun sebagian besar ahli fikih mazhab Imamiyah berpendapat bahwa seorang muslim boleh menikah dengan wanita ahl al-kitab dengan nikah munqati', tetapi tidak boleh dengan nikah dâim. Dalil mereka adalah penggabungan dalil yang melarang dan dalil yang membolehkan, dengan menafsirkan dalil yang melarang untuk nikah dâim, dan dalil yang membolehkan untuk nikah munqati, ${ }^{41}$

\footnotetext{
${ }^{40}$ Ibid., Jilid IX, 148.

${ }^{41}$ Ibid., Jilid IX, 355.
} 
Siapakah yang dimaksud dengan ahl al-kitab? Istilah banyak menimbulkan berbagai interprestasi. Sejumlah ulama membatasi ahl al-kitab kepada kelompok Yahudi dan Kristen di masa Nabi saja. Namun, jumhur ulama berpendapat bahwa yang dimaksud ahl al-kitab adalah Yahudi dan Nasrani, baik yang dijumpai pada masa Nabi saw, maupun yang hidup dijaman sekarang. Sebagian ulama lainnya, mengatakan bahwa istilah ahlul kitab terbatas hanya pada kelompok Yahudi dan Kristen, melainkan juga mencakup penganut agama Buddha dan Hindu, bahkan sebagian ulama menyebut agama lain, termasuk Majusi, agama Persia kuno dan agama orang-orang India, Cina dan Jepang. ${ }^{42}$

Menikahi perempuan ahl al-kitab, ulama sepakat membolehkannya. Perempuan ahlul Kitab sebagaimana disebutkan diatas adalah perempuan yang percaya terhadap agama samawi, seperti orang Yahudi dan Nasrani. Ahlul Kitab adalah para pemegang kitab Taurat dan Injil. Kebolehkan menikahi perempuan ahlul Kitab didasarkan atas surat al-Mâidah/5: 5: “...(Dan dihalalkan mangawini) wanita yang menjaga kehormatan di antara wanita-wanita yang beriman dan wanita-wanita yang menjaga kehormatan di antara orang-orang yang diberi al-Kitab sebelum kamu." Yang dimaksud dengan wanita yang menjaga kehormatan dalam ayat ini adalah para perempuan yang suci. Maksud ayat ini mendorong manusia untuk menikah dengan para perempuan yang suci, karena dalam perkawinan seperti ini terdapat rasa sayang dan cinta di antara suami-istri, serta menyebarkan rasa tentram dan tenang. ${ }^{43}$

Menurut Zuhaili, perkawinan dengan ahlul kitab dibolehkan karena ada sejumlah prinsip yang sama antara dua agama tersebut; pengakuan akan adanya Tuhan, keimanan kepada para utusan Tuhan, dan kepercayaan pada hari akhir. Beberapa prinsip ajaran ini menurutnya pada umumnya dapat menjamin "istiqomah" (stabilnya) kehidupan perkawinan mereka. Tetapi yang lebih menarik lagi adalah soal mengapa perkawinan itu hanya sah jika calon suaminya muslim, dan tidak sebaliknya?

\footnotetext{
${ }^{42}$ Ibnu Katsir, Tafsir Ibnu Katsir, Rasyid Rida, Tafsir Al-Manar, Jilid VI, 185 dan Jilid VI, 193.

${ }^{43}$ Wahbah al-Zuhailî, Fiqh Islam wa Adillatuhu, Jilid IX, 148-149.
} 
Kalau calon suaminya ahl al-kitab, menurut Wahbah tentu akan sangat mengkhawatirkan agama isterinya kelak. Istri bisa ditarik mengikuti agama suaminya. Dalam perkawinannya terdapat pengorbanan bagi perasaan dan akidahnya ${ }^{44}$ Artinya bahwa persoalan perkawinan beda agama menurut hukum Islam masih dipertentangkan kedudukannya oleh sebagian ulama.

\section{Fenomena Nikah Beda Agama di Indonesia}

Agama di Indonesia berperan penting dalam kehidupan masyarakat. Sila pertama dalam ideologi Pancasila adalah Ketuhanan Yang Maha Esa. Dalam UndangUndang Dasar (UUD) 1945 dinyatakan bahwa "tiap-tiap penduduk diberi kebebasan untuk memilih dan mempraktekkan kepercayaannya" Pemerintah secara resmi hanya mengakui enam agama di Indonesia yaitu: Islam, Protestan, Katolik, Hindu, Buddha dan Konghucu.

Saat ini kasus nikah beda agama di Indonesia makin marak. Meski pernikahan beda agama atau antar agama di Indonesia kian banyak jumlahnya, namun hingga kini belum mendapat tempat yang layak, baik dikalangan masyarakat, agamawan maupun pemerintah. Pernikahan seperti ini masih dianggap tabu, terlarang yang bertentangan dengan doktrin agama dan juga perundang-undangan negara Indonesia.

Menurut Ahmad Nurcholish ada empat faktor yang mempengaruhinya; Pertama, masyarakat pada umumnya hanya tahu bahwa doktrin agama yang dianutnya melarang pernikahan beda agama. Dan ini dipegang, sebagai pandangan atau tafsir tunggal terhadap teks-teks kitab suci yang membahas tentang masalah ini. Sayangnya sikap yang, demikian tidak dibarengi dengan telaah kritis terhadap teks-teks tersebut, sehingga mereka menerima apa adanya tafsir tunggal itu. Sikap yang cenderung dogmatis memiliki implikasi negative dimana apabila muncul tafsir yang berbeda yang membolehkan nikah beda agama, maka serta merta mereka menolak dengan sikap

\footnotetext{
${ }^{44}$ Ibid.
} 
antipasti; Kedua, demikian juga dengan para agamawan yang memiliki otoritas tunggal dalam menerjemahkan pesan kitab suci kepada umat, mereka, yang mayoritas bermazhab Syafii, cenderung berpegang kuat terhadap tafsir teks-teks kitab suci yang melarang pernikahan beda agama. Ini bisa dimaklumi, karena kebanyakan para mufassir (ahli tafsir) yang pernah ada memang memiliki pandangan demikian. Kalau ada ulama atau teolog yang menafsirkan teks-teks tentang pernikahan beda agama dibolehkan, jumlahnya sangat sedikit dibanding yang sebaliknya. Kondisi ini makin menegaskan bahwa larangan nikah beda agama yang tidak diragukan lagi kebenarannya. Ketiga, baik masyarakat, Organisasi keagamaan maupun agamawan (hampir) sepakat bahwa pernikahan beda agama akan rawan terhadap permasalahan rumah tangga. Antara lain: a) factor beda agama akan mudah memicu konflik yang dapat mengancam keutuhan rumah tangga, b) pada efek lanjutan akan dialami oleh anak-anaknya, dan mereka akan mengalami kebingungan dalam memilih agama, c) begitupun dalam masalah pembagian warisan akan dijumpai berbagai masalah. Tentu ada alasan-alasan lain yang sebenarnya sangat subjektif karena hanya menggunakan pendekatan asumtif semata. Keempat, pandangan masyarakat dan para agamawan tersebut makin kuat karena dilegalkan negara melalui UU Perkawinan Nomor 1 Tahun 1974 dan Kompilasi Hukum Islam (KHI) yang disahkan dengan Inpres Nomor 1 tahun 1991. Akibatnya, negara sama sekali tidak mengakomodir adanya pernikahan beda agama di Indonesia, terutama bagi Muslim dan Non Muslim. Ini diperkuat pula dengan fatwa MUI tanggal 1 Juni 1980 dan 2004 yang mengharamkan pernikahan beda agama, baik antara laki-laki Muslim dengan perempuan non Muslim, termasuk perempuan ahl al-kitab. ${ }^{45}$ MUI memahami mereka yang melakukan perkawinan beda agama tidak akan sakinah karena memiliki keyakinan yang berbeda, sehingga MUI mengharamkan dengan menggunakan kaidah fiqih sadd al-zarî’ah yaitu upaya preventif atau

\footnotetext{
${ }^{45}$ Ahmad Nurcholish Memoar Cintaku: Pengalaman Empiris Pernikahan Beda Agama (Yogyakarta: LKiS, 2004), 1-5.
} 
pencegahan. Menurut MUI perkawinan beda agama mendatangkan kerusakan lebih besar dari pada kebaikan yang akan diperoleh.

Menurut Undang-Undang Nomor 1 Tahun 1974 tentang Perkawinan disebutkan:

Perkawinan adalah ikatan lahir bathin antara seorang pria dengan seorang wanita sebagai suami isteri dengan tujuan membentuk keluarga (rumah tangga) yang bahagia dan kekal berdasarkan Ketuhanan Yang Maha Esa. ${ }^{46}$

Pengertian perkawinan terdapat lima unsur di dalamnya adalah: (a) ikatan lahir batin; (b) antara seorang pria dengan seorang wanita; (c) sebagai suami isteri; (d) membentuk keluarga (rumah tangga) yang bahagia dan kekal; dan (e) berdasarkan Ketuhanan Yang Maha Esa.

Menurut undang-undang tersebut dengan jelas menyatakan tujuan perkawinan adalah membentuk keluarga (rumah tangga) yang bahagia dan kekal. Demikian pula pada lima unsur didalam perkawinan disebutkan dalam huruf d, bahwa membentuk keluarga (rumah tangga) yang bahagia dan kekal.

Juga di dalam Alquran ada beberapa ayat yang memuat kata sakinah antara lain:

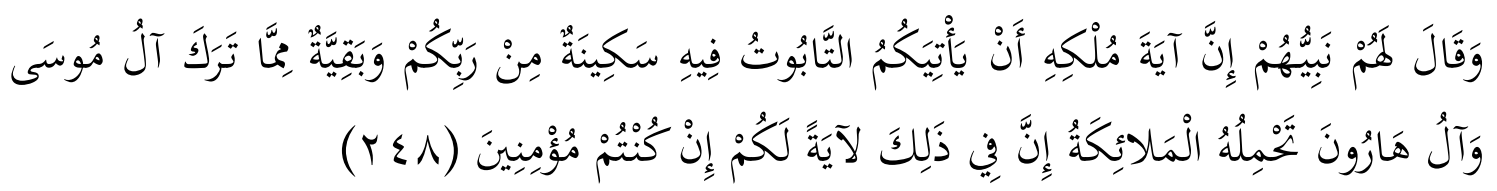

Terjemahnya:

Dan Nabi mereka berkata kepada mereka: "Sesungguhnya tanda kerajaannya ialah datangnya Tabut kepadamu, yang di dalamnya terdapat ketenangan dari Tuhanmu dan sisa dari peninggalan keluarga Musa dan keluarga Harun, yang dibawa oleh Malaikat." Sungguh, pada yang demikian itu terdapat tanda (kebesaran Allah) bagimu, jika kamu orang yang beriman (QS al-Baqarah/2: 248). ${ }^{47}$

Pengertian Tabut adalah peti tempat menyimpan Taurat yang membawa ketenangan bagi mereka. Ayat di atas menyebut, di dalam peti tersebut terdapat

\footnotetext{
${ }^{46}$ Republik Indonesia, Undang-Undang Nomor 1 Tahun 1974 tentang Perkawinan, Pasal 1.

${ }^{47}$ Kementerian Agama RI., Ummul Mukminin: Al-Qur'an dan Terjemahan untuk Wanita (Jakarta Selatan: Penerbit Wali, 2010), 40.
} 
ketenangan, yang dalam bahasa Alqutan disebut sakinah. Jadi, menurut ayat itu sakinah adalah tempat yang tenang, nyaman, aman, kondusif bagi penyimpanan sesuatu, termasuk tempat tinggal yang tenang bagi manusia.

Selanjutnya dalam kata sakinah disebut pula dalam firman-Nya:

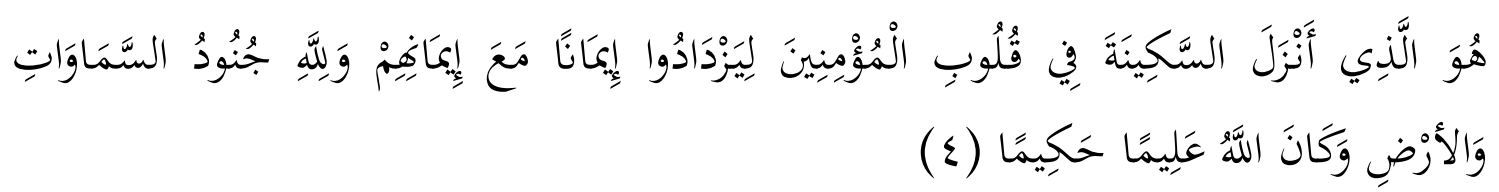

Terjemahnya:

Dialah yang telah menurunkan ketenangan ke dalam hati orang-orang mukmin untuk menambah keimanan atas keimanan mereka (yang telah ada). Dan milik Allah-lah bala tentara langit dan bumi, dan Allah Maha Mengetahui, Maha Bijaksana (QS al-Fath/48: 4). ${ }^{48}$

Quraish Shihab mengemukakan kata sakinah terambil dari bahasa Arab yang terdiri dari huruf-huruf sin, kaf, dan nun yang mengandung makna "ketenangan" atau antonim dari kegoncangan dan pergerakan. Berbagai bentuk kata yang terdiri dari ketiga huruf tersebut kesemuanya bermuara pada makna di atas. Misalnya, rumah dinamai maskan karena ia adalah tempat untuk meraih ketenangan setelah penghuninya bergerak bahkan boleh jadi mengalami kegoncangan di luar rumah. Menurutnya pula keluarga sakinah tidak datang begitu saja, tetapi ada syarat bagi kehadirannya. Ia harus diperjuangkan, dan yang pertama lagi utama, adalah menyiapkan kalbu. Sakinah atau ketenangan bersumber dari dalam kalbu, lalu terpancar ke luar dalam bentuk aktivitas. Memang Alquran menegaskan bahwa tujuan disyariatkannya pernikahan adalah untuk menggapai sakinah. Namun, itu bukan berarti bahwa setiap pernikahan otomatis melahirkan sakinah, mawaddah, dan rahmat." Kesemuanya membutuhkan perjuangan dan pengertian setiap keluarga. ${ }^{49}$

Saat ini tidak sedikit banyak keluarga yang gagal membina hubungan keluarga yang akhirnya bercerai di pengadilan. Merasa tidak bahagia, tidak tentram, tertekan dalam membina keluarga. Berbagai alasan mengajukan perceraian ada masalah

\footnotetext{
${ }^{48}$ Ibid., 511.

${ }^{49}$ M. Quraish Shihab, Perempuan (Jakarta: Lentera Hati, 2006), 141.
} 
cemburu, ekonomi, pihak ketiga, sampai masalah seks dalam hubungan suami istri. Kenyataan menunjukkan cukup banyak keluarga yang mengalami keretakan karena masalah-masalah tersebut dan yang melakukan perceraian di Pengadilan Agama adalah mereka yang seagama.

Fenomena perkawinan beda agama di Indonesia telah dipraktekkan secara aplikatif. Pernyataan dalam konsediran fatwa MUI 2015 bahwa belakangan ini disinyalir banyak terjadi perkawinan beda agama menunjukkan bahwa telah terjadi perkawinan beda agama. Beberapa penelitian menunjukkan bahwa di tengah masyarakat telah terjadi perkawinan muslim dengan non muslim. Diantaranya penelitian Nuryamin Aini tentang fenomena perkawinan beda agama di Yogyakarta tahun 1994. Nuryamin Aini menemukan fenomena dan angka-angka pelaku nikah beda agama meningkat secara signifikan. Pada tahun 1980, ia menemukan paling tidak terdapat 15 kasus. Pada tahun 1990, naik menjadi 18 kasus. Tetapi pada tahun 2000 menurun menjadi 12 kasus. Pelaku nikah beda agama, untuk sampel Yogyakarta, bukanlah trade-mark kalangan beragama masyarakat urban yang exclusive. Perikahan beda agama juga dilakukan oleh wong cilik ndeso. Nuryamin Aini menemukan banyak pasangan nikah beda agama yang buta huruf dan tak bisa berbahasa Indonesia. Sebelum tahun 2000, 50\% pernikahan beda agama dilakukan oleh orang desa, dengan tingkat pendidikan yang rendah, bukan hanya karena tamat Sekolah Dasar (SD) saja, tapi banyak juga yang tak pernah bersekolah. Secara umum, pernikahan beda agama di Yogyakarta merupakan refleksi dari eksotisme masyarakat Yogyakarta. ${ }^{50}$

Ahmad Nurcholish menulis Buku Memoar Cintaku Pengalaman Empiris Pernikahan Beda Agama. Buku ini mendeskripsikan pengalaman pribadi penulisnya menikah dengan Ang Mei Yong, gadis Tionghoa yang beragama Khonghucu. Pernikahan Ahmad Nurcholish dengan Ang Mei Yong dilangsungkan di Universitas Paramadina Jakarta 7 Juni 2013. Saksi atas perkawinan tersebut adalah Ulil Abshar-

\footnotetext{
${ }^{50}$ Mohammad Monib dan Ahmad Nurcholish, Fiqh Keluarga, 110-112.
} 
Abdalla dan Budi S. Tanuwibowo. Sedangkan walinya Prof. Dr. Kautsar Azhari, MA. Selain sebagai wali dan menikahkan, Prof. Kautsar juga yang menyampaikan khutbah nikah. ${ }^{51}$ Kini Ahmad Nurcholish pelaku perkawinan beda agama ini dipercaya sebagai Koordinator Program Konseling dan Advokasi Keluarga Harmoni Indonesian Conference on Religion and Peace (ICRP). Program ini memberikan pelayanan konseling, advokasi dan fasilitasi perkawinan beda agama. Sejak November 2005 hingga Desember 2007 telah mencatat seratusan pasang muda-mudi yang hendak melakukan perkawinan beda agama. Dari seratusan tersebut, tercatat sekitar 60 -an pasang yang berhasil menikah. Meskipun program ini ditutup, Ahmad Nurcholish masih memberikan fasilitasi. ${ }^{52}$

Ahmad Nurcholish mengemukakan bahwa ada lima prinsip dasar perkawinan dalam Islam yaitu:

1. Prinsip monogami, yaitu satu istri dan satu suami

2. Prinsip mawaddah warahma, yaitu cinta dan kasih sayang, ini menjadi fondasi dasar. Cinta dan kasih sayang inilah yang mempertemukan dua orang yang berbeda ini untuk mengarungi bahtera rumah tangga.

3. Prinsip saling melengkapi dan melindungi seperti disebutkan dalam QS alBaqarah/2: 187 لَهُنَّ لِبَاسُ وَأَنْنُم لَكُمْ لَبَاسُ هُنَّ (mereka adalah pakaian bagimu, dan kamupun adalah pakaian bagi mereka). Jadi suami adalah pakaian dari istri demikian pula sebaliknya. Artinya manusia menggunakan pakaian untuk melindungi manusia. Suami dan istri dimaksud untuk saling melindungi dan menjaga nama baik pasangan dan keluarga.

4. Prinsip mu'asyarah bil ma'ruf yaitu perintah untuk menggauli istri dengan baik yang dilakukan oleh suami. Sebagaimana Allah swt. berfirman dalam QS al-

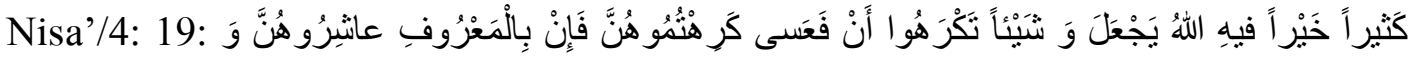

\footnotetext{
${ }^{51}$ Ahmad Nurcholish, Memoar Cintaku, 72.

${ }^{52}$ Mohammad Monib dan Ahmad Nurcholish, Fiqh Keluarga, xii-xiii.
} 
(Dan bergaullah dengan mereka secara patut. kemudian bila kamu tidak menyukai mereka, (maka bersabarlah) karena mungkin kamu tidak menyukai sesuatu, Padahal Allah menjadikan padanya kebaikan yang banyak).

5. Prinsip kebebasan untuk memilih pasangannya baik laki-laki maupun perempuan sebagai haknya, sepanjang tidak bertentangan dengan syariat. ${ }^{53}$

Inilah prinsip dasar perkawinan dalam Islam. Sepanjang lima prinsip dasar ini dilaksanakan oleh setiap orang apapun agamanya dan kemudian menikah maka akan meraih kebahagiaan atau sakinah, termasuk mereka yang telah membentuk keluarga dalam perkawinan beda agama. Dengan kata lain yang telah melakukan perkawinan beda agama jangan saling memaksakan keyakinan pasangannya untuk beralih keyakinan dan memaksakan, hal ini akan menjadi pemecah dalam keluarga.

\section{E. Kesimpulan}

Sebagian ulama mengharamkan secara mutlak tanpa membedakan ahl al-kitab, musyrik atau majusi, baik bagi perempuan muslim maupun laki-laki muslim. Keharaman ini didasarkan atas QS al-Baqarah/2: 221 dan QS al-Mumtahanah/60: 10. Sebagiannya ada yang membolehkan perkawinan beda agama, baik kebolehan itu bersyarat maupun tanpa bersyarat. Perkawinan beda agama boleh dengan syarat jika laki-laki muslim menikah dengan ahl al-kitab. Pendapat ini didasarkan kepada QS alMâidah/5: 5. Sedangkan boleh tanpa syarat adalah perkawinan antara muslim dan non muslim baik untuk laki-laki maupun perempuan. Perbedaan penyimpulan hukum perkawinan beda agama ini disebabkan oleh beberapa faktor. Salah satu diantaranya metode dan pendekatan yang digunakan dalam memahami teks Alquran sebagai sumber hukum yang menggunakan dua teori, yaitu teori tafsir dan teori ushul fikih.

Tujuan perkawinan yang membentuk keluarga sakinah atau bahagia dan tentram itu juga dimiliki oleh mereka yang telah menikah beda agama. Perkawinan

\footnotetext{
${ }^{53}$ Achmad Nurholish, Koordinator Program Konseling dan Advokasi Keluarga Harmoni ICRP, Focus Group Discussion, di Bali, 2019.
} 
beda agama dapat menjadi keluarga yang bahagia bila menerapkan lima prinsip dasar perkawinan dalam Islam.

Fatwa Majelis Ulama Indonesia (MUI) pada perkawinan beda agama atas kekhawatirannya diperkuat dengan kaedah fikih: "Mencegah kemafsadatan lebih didahulukan (diutamakan) dari pada menarik kemaslahatan”, dan kaedah sadd alżarî’ah. Karena MUI memandang perkawinan beda agama tidak mendatangkan kemaslahatan sebaliknya justu kerusakan yang ditimbulkannya lebih besar, sehingga untuk menghindari mafsadah ini dilakukan upaya preventif hukum dengan menggunakan metode sadd al-żarî'ah. Namun berdasarkan observasi dan kajian kepada pelaku perkawinan beda agama, maka tidak terjadi kepada mereka yang telah menikah beda agama. Pelaku perkawinan beda agama yang telah siap menikah beda agama bahkan sangat paham dengan perbedaan dan mengawali dengan cara saling menghargai perbedaan tersebut. Kebahagiaan sebuah keluarga tidak dapat diukur pada kesamaan teologi tetapi bagaimana mengatur dengan baik, saling menghargai dan memahami sebuah hubungan.

\section{Daftar Pustaka}

Alhamdani, H. S. A. Risalatun Nikah, terj. Agus Salim, Risalah Nikah: Hukum Perkawinan Islam. Jakarta: Pustaka Amani, 1980.

Dahlan R., M. dan Muhtarom. Menjadi Guru yang Bening Hati: Strategi Mengelola Hati di Abad Modern. Yogyakarta: Deepublish, 2016.

Darwis, Rizal. "Hak Nafkah Batin Istri dalam Perkawinan: Telaah Fikih dan Hukum Nasional Perspektif Jender," Disertasi. Makassar: UIN Alauddin Makassar, 2016.

Diener E., Oishi S., dan Lucas R. E., "Personality, Culture, and Subjective Well-being: Emotional and Cognitive Evaluations of Life. Annual Review of Psychology, Vol. 54 (2003); 403-425. doi: 10.1146/annurev.psych.54.101601.

Fakhruroji, Moch. Instal Ulang Hidupmu: Menyulut Nyali untuk Melawan Virus Kehidupan (Bandung: Dar Mizan, 2006. 
Galib M., Muhammad. Ahl al-Kitab Makna dan Cakupannya. Yakarta: Paramadina, 1998.

Hendrick C., dan Hendrick S. S., Close Relationship: A Sourcebook (California: SAGE Publication, Inc. 2000.

Hurlock, Elizabeth Bergner. Psikologi Perkembangan: Suatu Pendekatan Sepanjang Rentang Kehidupan, Edisi V (Jakarta: Erlangga, 1991.

Kamal, Musthafa, et. al. Fikih Islam. Yogyakarta: Citra Karsa Mandiri, 2002.

Kau, Sofyan A. P. Metode Penelitian Hukum Islam: Penuntun Praktis untuk Penulisan Skripsi dan Tesis. Yogyakarta: Mitra Pustaka, 2013.

. Tafsir Hukum Tema-Tema Kontroversial.Yogyakarta: Mitra Pelajar, 2013.

Kementerian Agama RI.. Ummul Mukminin: Al-Qur'an dan Terjemahan untuk Wanita. Jakarta Selatan: Penerbit Wali, 2010.

Khavari, Khalil A. The art Of Happiness: Menciptakan Kebahagiaan dalam Setiap Keadaan. Jakarta. PT. Serambi Ilmu Semesta, 2006.

Monib, Mohammad, dan Ahmad Nurcholish, Fiqh Keluarga Lintas Agama Panduan Multidimensi Mereguk Kebahagian Sejati. Yogyakarta: Kaukaba Dipantara, 2013.

Muhammad, Nova Effenty. "Perkawinan Beda Agama Menurut Tinjauan Hukum Islam: Studi Atas Fatwa MUI Tahun 2005," Disertasi. Makassar: UIN Alauddin Makassar, 2016.

Nurcholish Ahmad. Memoar Cintaku: Pengalaman Empiris Pernikahan Beda Agama. Yogyakarta: LKiS, 2004.

Pavot W. dan Diener E., "The Affective and Cognitive Context of Selfreported Measures of Subjective Well-being. Social Indicators Research, Vol. 28 (1993).

Al-Qarḍawî, Yûsuf. Fî Fiqh al-Aqalliyyât al-Muslimah Hayâh al-Muslimîn wast alMujtama'ât al Ukhrâ, terj. Adillah Obid, Fiqh Minoritas Fatwa Kontemporer Terhadap Kehidupan Kaum Muslimin di Tengah Masyarakat Non Muslim. Jakarta: Zikrul Hakim, 2004 M.

Al-Qâsimî. Tafsîr Mahâasin al-Ta’wîl, Jilid III. Beirût: Dâr al-Fikr, 1978.

Rakhmat, Jalaluddin. Meraih Kebahagiaan. Bandung: Simbiosa Rekatama Media, 2004.

Rasjidi, Lili. Hukum Perkawinan dan Perceraian di Malaysia dan di Indonesia. Bandung: PT Remaja Rosdakarya, 1991. 
Al-Râzî, Fakhr al-Dîn. Tafsîr al-Kabîr wa Mafâtîh al-Ghayb, Jilid XVI. Bairut: Dar alFikr, 1981.

Republik Indonesia. Undang-Undang Nomor 1 Tahun 1974 tentang Perkawinan.

Ridha, Rasyid. Tafsir al-Manar, Juz VI. Beirut: Dar al-Ma'arif, t. th.

Sabiq, Sayyid. Fiqh as-Sunnah, Juz II. Beirut: Dar al-Fikr, 1985.

Seligman, Martin. Aunthentic Happiness, Using the New Positive Psychology to Realize Your Potential for Lasting Fulfilment. New York: Free Press, 2002.

Shihab, M. Quraish. Tafsir al-Mishbah Pesan, Kesan dan Keserasian Al-Quran, Vol. 3. Jakarta: Lentera Hati, $1421 \mathrm{H} / 2001 \mathrm{M}$. . Perempuan. Jakarta: Lentera Hati, 2006.

Syalthut, Mahmud. Al-Islam 'Aqidah wa Syari'ah, terj. Bustami dan Hamdani, Akidah dan Syari'ah Islam. Jakarta: Bulan Bintang, 1972.

Talib, Sayuti. Hukum Kekeluargaan Indonesia. Cet. II; Jakarta: UI Press, 1982.

Al-Thabathab'i, Muhammad Husain. Al-Mizan fi Tafsir al-Quran, Juz XVI.Beirut: Mu'assasah al-'Alami li al-Mathbu'at, 1983.

Zuhailî, Wahbah. Al-Fiqh al-Islâmî wa Adillatuhu, terj. Abdul Hayyie al-Kattani, dkk. Fiqh Islam wa Adillatuhu, Jilid IX. Jakarta: Gema Insani Press, 2011.

https://kbbi.kemdikbud.go.id/entri/ 